\title{
JAN III SOBIESKI WOBEC KSIĘSTW RUMUŃSKICH I POWSTANIA WĘGIERSKIEGO
}

\author{
Ilona Czamańska \\ http://orcid.org/0000-0002-0492-0854 \\ Uniwersytet im. Adama Mickiewicza w Poznaniu
}

\section{ABSTRACT
JOHN III SOBIESKI TOWARDS THE ROMANIAN PRINCIPALITIES AND THE HUNGARIAN UPRISING

John III Sobieski had a significant part in the development of the Hungarian uprising which led to the Ottoman attack on Vienna, and which, in this way, posed a threat to Poland and Europe. The involvement in defending Vienna and establishing the "Holy League" forced a change of policy towards the Hungarians and directed expansion towards Moldova and Wallachia. The King of Poland, after taking over Podolia, which took place at the beginning of the war, and after failing to capture Kamianets-Podilskyi, could fight with the Turks only on the Moldovan (and possibly Wallachian) territory. Expansion in this direction, however, was not welcome by Emperor Leopold I, who considered these territories to be the rightful countries of the Hungarian domain. It was not possible to maintain the Moldovan throne under Stefan Petru, imposed in early 1684 by Poland. The next Moldovan rulers, Dumitru Cantacuzino and Constantin Cantemir, were strongly opposed to conducting anti-Turkish military activities in their country. The hopes of the Polish king for Constantin Cantemir's cooperation, despite some agreements, were not based on real grounds, and the political intentions towards the Romanian principalities were a factor here. Sobieski falsely assessed the mood prevailing in Moldovan society; while expecting general support, he met with resistance. Throughout the war, however, Imré Thököly tried to maintain the best possible relations with the King of Poland, persistently and yet unsuccessfully trying to lead to a separatist peace between the Ottoman state and the Polish-Lithuanian Commonwealth.

Keywords: John III Sobieski, Imré Thököly, Wallachia, Moldova, "Holy League”.

Słowa kluczowe: Jan III Sobieski, Imré Thököly, Wołoszczyzna, Mołdawia, „Święta Liga”. 
Wyprawę Jana III Sobieskiego pod Wiedeń rozpatruje się najczęściej w kontekście polityki europejskiej, zwłaszcza wobec najważniejszych graczy na arenie europejskiej - Francji i Habsburgów, a także oczywiście w kontekście relacji polsko-osmańskich. Umykają gdzieś ściśle związane z tym wydarzeniem sprawy południowych sąsiadów Polski. Nie doszłoby najprawdopodobniej ani do wyprawy osmańskiej na Wiedeń, ani do polskiej pod Wiedeń, gdyby nie wybuchło powstanie na Węgrzech.

Kryzys węgierski ciągnął się od lat 60 . XVII wieku, miał głębokie i skomplikowane podłoże. Podstawową sprawą było zachowanie odrębności i samodzielności Węgier, poszanowanie instytucji węgierskich, o co szlachta węgierska, pospołu z chorwacką, walczyć musiała od początku włączenia do monarchii Habsburgów. Doszło do tego niezadowolenie $\mathrm{z}$ wyniku wojny osmańsko-cesarskiej i nazbyt ugodowego stanowiska cesarza w pokoju w Vásvár w 1664 roku. Chorwaci musieli wówczas zwrócić Turcji liczne zdobyte tereny, a ich rozżalenie skutecznie podtrzymywały francuskie pieniądze. Był to jeden $\mathrm{z}$ niewielu w dziejach nowożytnych momentów, kiedy Francja była zainteresowana wojną z Osmanami w związku z tak zwanym konfliktem turbana i peruki. Jednak w końcu lat 60 . powoli zaczął się przełom w relacjach francusko-osmańskich, choć o powrocie do normalnych kordialnych stosunków można mówić dopiero od roku $1673^{1}$. Już w 1666 roku niezadowoleni z rządów habsburskich magnaci węgierscy podjęli potajemne rozmowy z Turcją Osmańską. Śmierć jednego z głównych animatorów spisku, palatyna Ferenca Wesselényiego osłabiła działalność spiskowców. Być może sprawa by ucichła, gdyby nie ujawnienie istnienia spisku i listy spiskowców, wśród których znalazły się wybitne osobistości, takie jak: najwyższy sędzia Ferenc Nádasdy, ban Chorwacji Péter Zrínyi (Petar Zrinski), jego szwagier Ferenc Kristóf Frangepán (Franjo Krsto Frankopan) oraz zięć Franciszek I Rakoczy. Wszyscy oni zostali skazani na śmierć, a wyrok wykonano 30 kwietnia 1671 roku w Wiedniu. Jedynie Franciszek I Rakoczy uniknął śmierci z ręki kata dzięki interwencji swej matki Zofii z Batorych, cieszącej się dużym szacunkiem na dworze cesarskim za powrót do katolicyzmu i wychowanie syna w tej religii ${ }^{2}$.

Likwidacja przywódców spisku spowodowała pewne wyciszenie buntowniczych nastrojów, powszechnie jednak zdawano sobie sprawę z ich istnienia, jak również z możliwości pozyskania przez opozycjonistów węgierskich wojskowej pomocy osmańskiej. W 1672 roku w Rzeczypospolitej niemal do końca wierzono, że przygotowywana przez sułtana wyprawa zostanie skierowana na pomoc Węgrom, a nie przeciw Polsce. Węgrom jednak brakowało przywódcy. Dopiero pojawienie się w 1677 roku młodego, zaledwie dwudziestoletniego Imrégo Thökölya, pozyskanie przez niego pomocy księcia siedmiogrodzkiego Mihálya Apáfiego i w końcu nawiązanie współpracy (i romansu zakończonego później małżeństwem) z energiczną wdową po zmarłym w 1676 roku Franciszku Rakoczym, Iloną Zrinyi, zmieniły sytuację.

A. Vandal, L'odyssée d'un ambassadeur. Les voyages du marqis de Nointel (1670-1680), Paris 1900, s. 15-20 i passim; C. Michaud, Raison d'état et conscience chrétienne. L'ambassade du marqis de Nointel auprès de la Porte Ottomane, „Revue des Études Sud-Est Européennes” 1979, t. XVII, p. 2, s. $257-267$.

2 G. Ágoston, T. Óborni, A tizenhetedik század története, Pannonica Kiadó 2000, s. 205-206. 
Wiele wskazuje jednak na to, że istotną rolę w rozwoju zbrojnych wystąpień na Węgrzech odegrali Ludwik XIV i Jan III Sobieski. Początki organizacji partyzantki kuruców zbiegają się z planami sojuszu polsko-francuskiego. W Polsce działania na rzecz Węgrów podjęte zostały bardzo wcześnie, co najmniej w październiku 1676 roku. Zaangażowani w nie byli przede wszystkim zwolennicy polityki profrancuskiej. Król być może jeszcze nie był w to bezpośrednio zaangażowany, w każdym razie twierdził, że o niczym nie wie ${ }^{3}$. Szczególnie aktywną rolę w organizacji sił zbrojnych odegrał chorąży wielki koronny i kawaler maltański Hieronim Lubomirski. Jako że Lubomirscy byli od pokoleń związani ze starostwem spiskim, niewątpliwie musieli dobrze znać mieszkających stale w Kieżmarku Thökölyów - zaangażowanie Hieronima mogło być po trosze rezultatem tej znajomości. Wiosną 1677 roku w tajemnicy przed ówczesnym hetmanem wielkim koronnym księciem Dymitrem Wiśniowieckim zaczął on w swoich majątkach zaciągać żołnierzy. Organizacja partyzantki węgierskiej była jeszcze wówczas w powijakach, wydaje się więc, że nie chodziło o to, by Węgrom w ich walce pomagać, lecz by ostry konflikt zbrojny wywołać. Inspiracja szła niewątpliwie od Ludwika XIV, który całkowicie przekonał do swych planów króla polskiego i naciskał na ich szybką realizację. Za francuskie pieniądze zbierano oddziały również w dobrach królewskich - Stryju i Samborze - z zamiarem wysłania na Węgry. Jesienią dowiedział się o nich Wiśniowiecki, uznał je za bezprawne i wielce niebezpieczne dla kraju. Napisał wówczas list do króla z zapytaniem, co powinien uczynić w tej sytuacji, jednak nie otrzymał żadnej konkretnej odpowiedzi. Rozesłał więc uniwersały zakazujące nieformalnych zaciągów, a także nakazał hetmanowi polnemu, Stanisławowi Jabłonowskiemu, zbrojną ich likwidację . Zażądał też wyjaśnień w tej sprawie od Węgrów uczestniczących w komisji granicznej. Te oficjalne działania hetmana wielkiego ostrzegły króla i potajemnie przygotowującego oddziały Hieronima Lubomirskiego, toteż pospiesznie wyprowadzono je z kraju, zanim Wiśniowiecki zdołał doprowadzić do ich zniszczenia ${ }^{5}$. Mimo prób ułagodzenia Wiśniowieckiego książę poglądów swoich nie zmienił i ostro sprzeciwił się wszelkim próbom angażowania się w antycesarskie działania na Węgrzech. Rozpowszechniano nawet nieprawdziwe pogłoski, że kazał rozstrzelać jednego z przywódców powstańców węgierskich, Pála Wesseléniego ${ }^{6}$. Oddziały Lubomirskiego walczyły na Węgrzech na przełomie 1677 i 1678 roku, umożliwiając

3 François de Bethune w liście do Simona A. Pomponne'a z 26 X 1676 r. wspominał o pogłoskach na temat działań antycesarskich prowadzonych przez wojewodę ruskiego (Stanisława Jabłonowskiego), kawalera maltańskiego Hieronima Lubomirskiego oraz stolnika (Jana Wielopolskiego). Ten ostatni wyrażał przekonanie, że ruch węgierski jest nie do powstrzymania. W tym samym czasie biskup krakowski Andrzej Trzebicki pisał o pogłoskach na temat zaciągów wojskowych w celu udzielenia pomocy Węgrom (Archiwum Spraw Zagranicznych Francuskie do dziejów Jana Trzeciego, t. 1, wyd. K. Waliszewski, Kraków 1879, s. 320).

4 Dymitr Wiśniowiecki do Michała Kazimierza Paca, b.d., Biblioteka XX. Czartoryskich w Krakowie, rkps 412, s. 82-84 [dalej: B. Czart.]; zob. też korespondencję Jana Andrzeja Morsztyna i depeszę de Bethune'a z IX 1677 r., Archiwum Spraw Zagranicznych Francuskie..., s. 438-439.

5 Dymitr Wiśniowiecki do Michała Kazimierza Paca, b.d., B. Czart., rkps 412, s. 82-84.

6 François de Bethune do Ludwika XIV, 9 VI 1678, Archiwum Spraw Zagranicznych Francuskie..., s. 83. 
Thökölyowi opanowanie Górnych Węgier7. Jeszcze w 1680 roku Imré Thököly pisał, że król francuski obiecał mu pomoc za pośrednictwem Polski ${ }^{8}$.

Niewątpliwie więc działania króla polskiego rozdmuchały tlący się ogień na Węgrzech i pożar, jaki z niego powstał, rychło okazał się na tyle niebezpieczny dla Rzeczypospolitej, że zmusił Sobieskiego do całkowitego przewartościowania swej dotychczasowej polityki i wejścia w sojusz z Habsburgami. W rezultacie przyszło więc Sobieskiemu walczyć z powstaniem, do którego rozwoju sam się w pewnym sensie przyczynił i to mimo jego osobistej sympatii do powstańców.

Król polski bardzo szybko przekonał się, że najbardziej niebezpiecznym dla rządzonego przez niego państwa pozostawało wówczas Imperium Osmańskie. Rzeczpospolita miała $\mathrm{z}$ nim długą i niezbyt jasno określoną granicę, co groziło w każdej chwili konfliktem. W dodatku imperium rościło sobie pretensje do terenów Ukrainy znajdujących się wówczas pod panowaniem moskiewskim i część z nich rzeczywiście udało mu się sobie podporządkować. Pod koniec wojny rosyjsko-tureckiej lat 1677-1681 Sobieski zupełnie poważnie myślał o wznowieniu wojny z Turcją po stronie Rosji. Rozmowy na ten temat były już daleko posunięte, jedynie zawarcie pokoju w Bachczysaraju powstrzymało króla polskiego od rozpoczęcia działań wojennych. Nic więc dziwnego, że kiedy po zawarciu traktatu wzrosło zagrożenie osmańskie dla monarchii Habsburgów, zwrócił się on politycznie w kierunku cesarza.

Gdy sojusz i współpraca militarna Jana III z cesarzem Leopoldem stały się faktem, w relacjach z Węgrami nastąpiła swoista schizofrenia. Król polski starał się unikać konfrontacji zbrojnej z Węgrami Thökölya, przekonując przywódcę powstania, że jego działania nie są skierowane przeciwko niemu, lecz przeciw Turkom i tym Węgrom, którzy Turków popierają, a przecież to sam Thököly stał na ich czele. Sobieski tworzył w ten sposób złudzenie potencjalnej możliwości odciągnięcia powstańców węgierskich od sojuszu z sułtanem ${ }^{9}$, co w ówczesnych warunkach nie miało szans powodzenia. Węgrzy również mieli nadzieję, że uda im się odciągnąć Sobieskiego od antyosmańskiej koalicji z cesarzem. Rozmowy trwały praktycznie nieprzerwanie, dopóki Imré Thököly nie został internowany, i to przez swoich sprzymierzeńców. Krótko po zwycięstwach pod Wiedniem i Parkanami nęcono Sobieskiego mirażem korony Węgier, dla niego lub jego syna, trudno jednak było traktować to w pełni poważnie. Oczywiście pozostając w sojuszu z cesarzem, król polski nie mógł angażować się aktywnie ani w politykę węgierską, ani w samodzielne działania zbrojne na terenie Węgier - był to teren zastrzeżony dla cesarza jako króla Węgier.

Jedynym obszarem, na którym Sobieski mógł i powinien prowadzić działania wojenne, były księstwa rumuńskie, ale i tu sytuacja pozostawała skomplikowana.

7 O współpracy polsko-francuskiej na Węgrzech zob. też: C. Michaud, Le soleil, l'aigle et le croissant. L'ambassade de Guilleragues à la Porte Ottomane et le siège de Vienne de 1683, „Revue des Études Sud-Est Européennes" 1984, t. XXII, p. 2, s. 146.

8 Imré Thököly do Mihálya Teleki, 26 IV 1680, Gróf Thököly Imré levelei, Budapest 1882, s. 114 115.

9 Brat István do Anny Bornemissy, małżonki księcia siedmiogrodzkiego, 24 XI 1683, Monumenta Hungariae Historica, Erdélyi Országgyülési Emlékek, t. XVIII (og. zb. XXX), ed. S. Szilágy i, Budapest 1895, s. 170-171. 
W dobie wyprawy wiedeńskiej hospodarem mołdawskim był Jerzy Duca. Za jego rządów dominującą rolę w państwie odgrywała propolska partia bojarska, na której czele stał wielki logofet Miron Costin. Mimo to hospodar ten nie cieszył się zaufaniem ani poparciem króla polskiego. Przyczyn takiego stanu rzeczy było kilka. Najpoważniejszą z nich była sprawa Ukrainy. Sułtan mianował w 1681 roku hospodara mołdawskiego namiestnikiem Ukrainy. Jerzy Duca przyjął to stanowisko i główną swą siedzibę przeniósł do Niemirowa. Król polski uznał to za akt przeciwko Rzeczypospolitej ${ }^{10}$.

W negatywnym nastawieniu do Jerzego Duki utwierdzała niewątpliwie króla emigracja mołdawska. Dużą jej część stanowili zbiegli przywódcy i uczestnicy nieudanego powstania przeciw Jerzemu Duce z roku 1668. Mihalcea Hîncu i Apostol Durac walczyli z całymi swoimi oddziałami w armii koronnej i wielce przysłużyli się w czasie działań wojennych prowadzonych na terenie Mołdawii w latach 1673-1674. Przypomnijmy, że walki te miały na celu między innymi ponowne osadzenie na tronie Stefana Petru, nazywanego w Polsce Petryczejką. Był on hospodarem mołdawskim w latach 1672-1673 i bardzo ściśle współpracował z Polską przeciw Imperium Osmańskiemu. W dobie wyprawy wojsk Rzeczypospolitej pod Chocim jeszcze wyraźniej zadeklarował swój udział w walkach z Turkami po stronie polskiej - na kilka dni przed bitwą uciekł do obozu polskiego z częścią swych wojsk ${ }^{11}$. Po zwycięskiej bitwie zastępujący Sobieskiego Mikołaj Sieniawski pomógł Petryczejce w powrocie na tron, jednak zakończenie kampanii i wycofanie wojsk polskich z mołdawskiej stolicy zmusiło tegoż do wyjazdu z Mołdawii ${ }^{12}$. Odtąd były hospodar zamieszkał na stałe $\mathrm{w}$ Polsce. O tronie mołdawskim nie przestał myśleć, jednak w latach siedemdziesiątych jego zdobycie wydawało się mało prawdopodobne. Wobec przystąpienia Rzeczypospolitej do rozmów pokojowych z Imperium Osmańskim sejm w 1676 roku nadał indygenat Stefanowi Petryczejce, jego krewnym oraz współpracownikom: Janowi i Mikołajowi Hyżdeu (rum. Hîjdeu), Apostolowi Catargiu, Grigoremu Hăbăşescu i Jakubowi Halipińskiemu ${ }^{13}$. Na tym samym sejmie odrębnym aktem na prośbę hospodara nobilitowane zostały towarzyszące mu osoby: Michał i Jan Con-

10 E. Hurmuzaki, Documente privitoare la istoria românilor, supl. 2, vol. 3, Bucuresci 1900, s. $139 \mathrm{in}$.

11 Pisma do wieku i spraw Jana Sobieskiego, t. 2, wyd. F. Kluczycki, Kraków 1881, s. 1318; Archiwum PAN Warszawa, sygn. III-198 (Materiały J. Wolińskiego), nr 91, k. 95; I. Czamańska, Oswobodziciel czy najeźdźca? Polityka Jana III Sobieskiego wobec hospodarstw Moldawii i Woloszczyzny, „Roczniki Historyczne” 1989-1990, R. XV-XVI, s. 156 (w pracy tej omówiłam wszystkie problemy dotyczące polityki mołdawskiej i wołoskiej króla polskiego szerzej niż w niniejszym artykule, zainteresowanego czytelnika kieruję więc do tej publikacji, rezygnując z odsyłaczy do niej niemal w każdym przypisie).

12 J. Woliński, Po Chocimie 1673-1674 [w:] idem, Z dziejów wojen polsko-tureckich, Warszawa 1983, s. 60-80.

13 Volumina legum [dalej: VL], t. V, Petersburg 1860, s. 198; E. Hurmuzaki, op. cit., supl. 2, vol. 3, s. 108-109; Z. Wdowiszewski, Regesty przywilejów indygenatu w Polsce (1519-1793), Materiały do biografii, genealogii i heraldyki polskiej, t. 5, Buenos Aires-Paryż 1971, s. 39-40; I. Czamańska, Rumuńska imigracja polityczna w Polsce XVII wieku, „Balcanica Posnaniensia. Acta et Studia” 1993, t. VI, s. 18. 
drati, Jerzy i Miron Hyżdeu, Kiriaki Papara, Bazyli Turkuł, Konstanty Korabataki, Bazyli Kupara i Bazyli Poponiec ${ }^{14}$. Kilka lat wcześniej indygenat otrzymał wspomniany Apostol Durac ${ }^{15}$.

Nie znaczy to, że w Mołdawii zabrakło zwolenników dobrej współpracy z Rzecząpospolitą. Duże wpływy miał inny mołdawski polonofil, Miron Costin. Nie był on zwolennikiem Petryczejki, zwłaszcza że ten swego czasu usunął go z bardzo wysokiego stanowiska wielkiego dwornika Ziemi Dolnej. Choć wychowany i wykształcony w Polsce, Costin obawiał się otwartego z nią sojuszu i konfliktu z osmańskim suzerenem, ostro potępił decyzję Petryczejki otwartego przejścia na stronę Polski i w 1674 roku podjął działania dyplomatyczne w imieniu nowo mianowanego przez sułtana hospodara - Dumitraszki Cantacuzino. Celem jego misji miało być skłonienie Polaków do ewakuacji mołdawskich twierdz zdobytych w czasie kampanii pochocimskiej ${ }^{16}$. Misja ta nie zakończyła się wprawdzie sukcesem, lecz okazała się istotna ze względu na nawiązanie ściślejszych osobistych kontaktów między Costinem a przyszłym królem Polski oraz jego osobistym przyjacielem - Markiem Matczyńskim. Nieco później, w dobie polsko-osmańskich negocjacji pokojowych, poseł polski Jan Gniński wykorzystywał przychylność Costina, który był wówczas wielkim logofetem, do utworzenia w Jassach punktu pocztowego, kanclerz mołdawski natomiast zabiegał o zagwarantowanie w polsko-osmańskim układzie pokojowym zachowania dotychczasowego statusu politycznego Mołdawii ${ }^{17}$. Tę dobrą współpracę przerwała jednak dymisja Costina i usunięcie go ze stanowiska kanclerza. Przestał działać punkt pocztowy w Jassach, co Polacy natychmiast odczuli, tracąc możliwość bezpośredniego szybkiego kontaktu z krajem ${ }^{18}$.

Niewątpliwie król Jan III oraz jego najbliższe otoczenie cenili Mirona Costina i byli przekonani o jego życzliwości. O rozwoju serdecznych kontaktów świadczy napisane bezbłędną polszczyzną dziełko kanclerza mołdawskiego Chronika Ziem Mołdawskich i Multańskich dedykowane Markowi Matczyńskiemu. Jako liczący się polityk, nawet chwilowo zdymisjonowany, Costin miał w Mołdawii potężne stronnictwo polityczne składające się w znacznej mierze z jego braci i innych krewnych. Potrafiło ono skutecznie działać także w Porcie Otomańskiej, doprowadzając w krótkim czasie do politycznego przewrotu w Mołdawii, aresztowania panującego hospodara Antoniego Ruseta i mianowania Jerzego Duki. Miron Costin powrócił na swe stanowisko wielkiego logofeta, prowadził politykę przyjazną Polsce, ale realistyczną,

14 VL, t. V, s. 201.

15 Ibidem, s. 76.

16 Pisma do wieku i spraw Jana Sobieskiego, t. 1, s. 1425; I. Czamańska, Miron Costin. Życie i twórczość [wstęp do:] M. Costin, Latopis Ziemi Moldawskiej i inne utwory historyczne, thum. I. Czamańska, Poznań 1998, s. 28-29.

17 M. Costin do Marka Matczyńskiego, 30 VI 1676, AGAD, Archiwum Zamoyskich [dalej: AZ], 2872, s. 49-52.

18 Źródła do poselstwa Jana Gnińskiego wojewody chełmińskiego do Turcji w latach 1677-1678, wyd. F. Pułaski, Warszawa 1907, s. 9, 219-230, 257 i in. 
unikając konfliktu z Imperium Osmańskim, a nie gardząc też zapewne i profitami. W Polsce uważano go jednak za polonofila, całą nieufność przekładając na Dukę ${ }^{19}$. Mimo to za jedyną osobę, na której można polegać, uważano wówczas Petryczejkę, choć nieco obawiano się jego kontaktów z Moskwą. Wyruszając pod Wiedeń, Jan III Sobieski zwrócił się do Petryczejki w liście: „Nam nie zostaje, tylko jak najskuteczniej zagrzać onego, abyś sprawiwszy o tym jak najskuteczniej ziemię swoją i przyjaciół, cokolwiek tam masz kredytu, wiary, znajomości, konfidencyjej na to łożył i obrócił, jakoby się mógł tamten kraj postrzec, a do spólnych chrześcijańskich przywiązawszy się szabel, kiedyżkolwiek pogańskie zrzucić jarzmo" ${ }^{20}$. Wyprawa, w której wzięły udział mołdawskie oddziały Petryczejki oraz kozackie Stefana Kunickiego, nie spełniła jednak swej roli jako dywersji, gdyż wyruszyła dopiero w końcu listopada 1683 roku, a więc w momencie, gdy wojska biorące udział w odsieczy już powracały do kraju. Mimo to udało się jeszcze opanować część Mołdawii, zanim powrócił do niej Jerzy Duca, który jako lennik turecki musiał wziąć udział w walkach w obozie Kara Mustafy.

Mimo niekorzystnej sytuacji Duca zdecydował się wrócić do kraju i zawalczyć o utrzymanie tronu. Sam autorytet (zakładając, że go miał) nie wystarczył jednak do odzyskania władzy, zabrakło armii, która rozpierzchła się po klęsce wojsk osmańskich. W dodatku w początkach stycznia do walk w Mołdawii włączyli się również Polacy, oddział pułkownika Dymideckiego otoczył i wziął do niewoli Jerzego Dukę wraz z towarzyszącymi mu bojarami, wśród których znajdował się również Miron Costin ${ }^{21}$. Jeńców potraktowano bardzo łagodnie, zwłaszcza po tym, jak rozpoznano Costina, którego traktowano jak przyjaciela. Byli, zapewne za poręczeniem słownym, osobiście wolni, Duca zamieszkał we Lwowie, Costin korzystał z gościny królewskiej, przebywając w należącym do króla pałacu myśliwskim w Daszawie ${ }^{22}$.

Tymczasem po wycofaniu się Polaków Stefan Petryczejko po raz kolejny zmuszony został do wycofania się z Mołdawii. W marcu 1684 roku wkroczył do Mołdawii mianowany przez sułtana Dumitraşcu Cantacuzino, mający opinię zdecydowanego wroga Polaków. Przekonany o tym Sobieski nawet nie próbował się z nim kontaktować. Zresztą właśnie wówczas zawarty został sojusz Ligi Świętej i król polski nastawiony był na wojnę. Podejmując przygotowania do niej, starał się zaangażować liczną, lecz skłóconą imigrację mołdawską oraz mniej liczną imigrację wołoską, skupioną wokół byłego hospodara Constantina Şerbana. W celu ustalenia planu wspólnych działań na dzień 25 lipca 1684 roku zwołana została do Żółkwi

19 I. Moga, Rivalitatea polono-austriacă şi orientarea politică ţărilor române la sfârşitul secolului XVII, Cluj 1933, s. 80-87; I. Czamańska, Miron Costin. Życie i twórczość, s. 32-33.

20 Jan III do Stefana Petryczejki, Kraków, 14 VIII 1683, Bibl. Kórnicka PAN, rkps 387, k. 32.

21 „Ducas autem Princeps a Dno Dimidecki captus est in manus D-ni Wilczyński Centurionis Soczaviae sub custodia est vir magnus et dives opum, pro quo hunc deducendo expedita sunt aliquot vexilla Leopoli, capti cum illo insperate Mironosko Costenus Mareschalcus et alii complures dignitarii”, A. Załuski, Epistolarium historico-familiarium, t. 1, p. 2, Brunsbergae 1709, s. 901.

22 C. Chow aniec, Miron Costin en Pologne, Contributions a l'année 1684-1685, nadb. z Închinare lui Nicolae Iorga, Cluj 1931, s. 2-3. Z. Spieralski mylnie sądził, że Costin wydał Dukę Petryczejce Z. Spieralski, Awantury mołdawskie, Warszawa 1967, s. 198. 
narada wszystkich środowisk imigranckich. Miała ona bardzo uroczystą oprawę. Miron Costin napisał $\mathrm{z}$ tej okazji swój poemat w języku polskim Historyja polskimi rytmami o Wotoskiej Ziemi i Multanskiej, w którym wbrew dotychczasowym swym poglądom zamieścił słowa zachęty dla króla polskiego, by zbrojnie uwolnił Mołdawię spod tureckiego jarzma ${ }^{23}$.

Petryczejko i skupieni wokół niego bojarzy wystosowali suplikę do Jana III, w której poddawali Mołdawię pod zwierzchnictwo króla polskiego, żądając jednak w zamian praw politycznych, takich jakie posiadała szlachta polska ${ }^{24}$. Przygotowywana latem tego roku wyprawa do Mołdawii nie doszła jednak do skutku ze względu na fatalną pogodę - padające deszcze uniemożliwiły bowiem przeprawę przez Dniestr.

W roku następnym nie udało się w porę przygotować odpowiedniej armii. Mimo to hetman wielki koronny Stanisław Jabłonowski zdecydował się wkroczyć do Mołdawii. Był to falstart, zważywszy na fakt, że krótko przed rozpoczęciem działań wojennych zmienił się hospodar i nie podjęto nawet żadnych prób porozumienia. Tymczasem przeświadczenie o przyjaznych Polakom nastrojach ludności rychło uległo weryfikacji, zwłaszcza że nowy hospodar, Constantin Cantemir, okazał się bardzo skuteczny w walkach z wojskami polskimi.

Nie wiemy, czy w wyprawie Jabłonowskiego wziął udział Petryczejko, ale w tym czasie zaczął on tracić wpływy na dworze króla polskiego, który wyraźnie odstąpił od zamiaru osadzenia go na tronie mołdawskim ${ }^{25}$. Niewątpliwie dojrzewał wówczas plan utworzenia w Mołdawii udzielnego księstwa dla królewskiego syna Jakuba. Jednocześnie Sobieski zdawał sobie sprawę, że bez pomocy, czy przynajmniej neutralności, panującego hospodara trudno mu będzie skutecznie prowadzić działania wojenne na terenie Mołdawii, zwłaszcza w oddaleniu od polskich granic, ze względu na trudności aprowizacyjne, co pokazały już wielokrotnie wyprawy podejmowane do Mołdawii w latach poprzednich. Możliwe też, że bardziej przekonujący okazał się konkurencyjny wobec Petryczejki polityk mołdawski przebywający w Polsce - Mi-

23 Ostatnia edycja: M. Costin, op. cit., s. 275-306.

24 Suplika i żąania panów bojarów wołoskich imieniem catej Ziemi do Najjaśniejszego i Niezwyciężonego Majestatu Jana Trzeciego, króla polskiego i catej Rzeczypospolitej podana w Żótkwi roku 1684 mca lipca 25 dnia, oryg.: AGAD, AZ 3028, s. 133-134; kopia z 1684 r.: BN, Biblioteka Ordynacji Zamoyskich, rkps 1188, k. 9; druk: E. Hurmuzaki, op. cit., supl. 2, vol. 3, s. 151. Suplikę tę wręczyli królowi bojarzy mołdawscy z Petryczejką na czele, o czym informował sam hospodar w liście do króla: AGAD, Archiwum Publiczne Potockich [dalej: APP] 47, t. 2, s. 85-86 i 89-90. C. Chowaniec, $Z$ dziejów powiedeńskiej polityki Jana III. Do genezy sprawy wschodniej, „Przegląd Współczesny” 1929, R. 8, t. XXX, s. 333. Później wybuchła dyskusja na temat autora supliki, przypisywano ją Mironowi Costinowi (С. Chow aniec, Miron Costin en Pologne..., s. 5-6) lub różnym grupom bojarskim (Л.В. Власова, Молдавско-польские политические связи в последней четверти XVII-XVIII вв., Кишинев 1980, s. 34-38; Z. Wójcik, Jan Sobieski 1629-1696, Warszawa 1983, s. 367-368).

25 Możliwe, że rezygnując z zamiaru osadzenia Petryczejki na tronie, król w sposób bardziej energiczny podjął starania o jego zaopatrzenie na terenie Rzeczypospolitej, czego świadectwem może być uchwała sejmu z roku 1685 zobowiązująca do wypłacenia mu z pierwszych wpływów podatkowych naznaczonej mu przy indygenacie pensji $20000 \mathrm{zł}$ oraz niewypłaconych pensji za poprzednie lata (do tego roku nie wypłacono ani jednej), VL, t. V, s. 349. 
ron Costin, który oferował się przekonać nowego hospodara do podjęcia współpracy z królem polskim.

W grudniu 1685 roku Costin wyruszył do Mołdawiii ${ }^{26}$. Cantemir przyjął go bardzo dobrze i robił wrażenie chętnego do porozumienia, jednak rozmowy trwające całą wiosnę 1686 roku nie dały żadnych konkretnych rezultatów, a główny negocjator otrzymał stanowisko starosty na Putnie - najbardziej na południe wysuniętego okręgu w kraju. Lepiej natomiast powiodły się pertraktacje $\mathrm{z}$ hospodarem wołoskim Şerbanem Cantacuzino. Już od dawna współpracował on z Ligą Świętą, bliższe były jednak jego związki z Cesarstwem. Z Sobieskim utrzymywał kontakty jego brat, Constantin. Tym razem obiecywał Sobieskiemu daleko idącą pomoc. Według planu hospodar wołoski miał wystawić 30000 wojska i połączyć się z królem polskim na terenie Mołdawii.

Latem 1686 roku armia Sobieskiego stanęła na granicy mołdawskiej. W zamierzeniu miała przejść przez obydwa księstwa rumuńskie i zaatakować bezpośrednio terytoria tureckie. $\mathrm{Z}$ hospodarem mołdawskim nadal nie było jednak porozumienia, ale plany króla polskiego w stosunku do Mołdawii też temu porozumieniu nie sprzyjały. W wyprawie towarzyszył mu najstarszy syn Jakub, którego zamyślał osadzić na tronie mołdawskim. Jednocześnie jednak Sobieski grał na dwa fronty. Już wchodząc do Mołdawii, podjął kolejną próbę porozumienia z Cantemirem, wysyłając do niego jezuitę Wierzchowskiego z propozycją przejścia na jego stronę w zamian za dziedziczny tron Mołdawii i pierwsze miejsce w sejmie Rzeczypospolitej. Hospodar odpowiedział bardzo grzecznie, że chętnie przeszedłby na stronę króla polskiego, nie może jednak tego uczynić, gdyż jego syn znajduje się jako zakładnik w Konstantynopolu i wojska osmańskie stacjonują na terenie Mołdawii. Obiecywał natomiast poddać się królowi w przypadku zwycięstwa wojsk polskich, sam ze swej strony czynił jednak wszystko, by do tego zwycięstwa nie doszło, między innymi przekazując szczegółowe informacje Turkom i Tatarom o ruchach armii Sobieskiego ${ }^{27}$. Nieco lepsze nadzieje budziła współpraca hospodara wołoskiego, jednak wbrew pierwotnym

26 Sprawa datacji wezwania i wyruszenia M. Costina do Mołdawii nie jest zupełnie jasna. Czesław Chowaniec na podstawie kopii znajdującej się przed II wojną światową w zbiorach Aleksandra Czołowskiego opublikował list brata Mirona Weliczki wzywający byłego kanclerza mołdawskiego do powrotu datowany na 17 września 1685 roku (C. Chow aniec, Miron Costin en Pologne..., s. 9). Kopia ta zaginęła, zachowała się natomiast inna kopia listu sporządzona ręką samego Mirona Costina, datująca list z Jass dopiero na 18 XI (Copia listu od Rodzonego do mnie de data z Jass 18 novembris 1685, AGAD, APP 47, t. 1, s. 277-278). Witold Wasilewski, analizując kampanię Stanisława Jabłonowskiego z roku 1685, zwrócił uwagę na notatkę hetmana z dnia 26 IX o przejęciu listu od Weliczki do Mirona (W. Wasilew ski, Wyprawa bukowińska Stanisława Jabłonowskiego w 1685 roku, Warszawa 2002, s. 114). Niewątpliwie jednak list ten nie dotarł do adresata, a przynajmniej nie od razu. Jeszcze 6 XI Miron Costin pisał do Stanisława Szczuki, że nie ma żadnych wiadomości od rodziny z Mołdawii. Możliwe, że nie mogąc doczekać się odpowiedzi, Weliczko wysłał drugi list 18 XI, albo też wówczas dopiero Miron otrzymał korespondencję zatrzymaną przez hetmana. Tak czy inaczej do Mołdawii mógł wyruszyć najwcześniej w XII 1685 roku.

27 C. Chowaniec, Wyprawa Sobieskiego do Mołdawii w 1686 r., Oświęcim 2015, s. 54-55; D. Cantemir, Viaţa lui Constantin Cantemir, Bucureşti 1973, s. 104-107; Gh. Duznichevici, Ceva nou asupra legăturilor lui Sobieski cu Moldova, AR MSI, ser. III, t. 19, mem. 21, Bucureşti 1937, s. 287. 
zamierzeniom nie połączył się on z królem polskim w Mołdawii, lecz ostrożniej oczekiwał wojsk polskich na Wołoszczyźnie ${ }^{28}$.

Udało się natomiast Sobieskiemu pozyskać niektórych bojarów i część prawosławnego duchowieństwa, zwłaszcza że patriarchowie wschodni nawoływali do udzielania pomocy wojskom Ligi Świętej. Gdy król polski wkroczył do nieobronnych i opuszczonych przez hospodara Jass, witali go uroczyście dostojnicy cerkiewni z chorągwiami i przyjmował metropolita suczawski Dosoftei ${ }^{29}$. Nie wystarczyło to jednak do sukcesu kampanii, która ostatecznie zakończyła się fiaskiem. Jedną z przyczyn niepowodzenia było spalenie magazynów żywności w monasterach w Jassach i wokół Jass. Spowodowało to wielki pożar w mieście, o którego wywołanie później niesłusznie oskarżano Sobieskiego. Wygląda raczej na to, że były to działania o charakterze sabotażowym. Ewakuacja wojsk polskich z Mołdawii postawiła w trudnej sytuacji metropolitę Dosofteia, który ostatecznie zdecydował się opuścić Mołdawię wraz z wojskami polskimi. Sędziwy metropolita zabrał jednak ze sobą wszystko to, co uważał za najcenniejsze: relikwie Świętego Jana Nowego i błogosławionej Paraskewii oraz szaty i naczynia liturgiczne. Po przyjeździe do Polski osiadł w Żółkwi, prywatnym mieście Sobieskich, i nie reagował na liczne wezwania hospodara do powrotu do kraju i oddania wywiezionych rzeczy. Zmarł w Żółkwi w 1693 roku, jednak pozostałe po nim przedmioty nie zostały za życia Jana III zwrócone. Casus Dosofteia dał podstawę do również niesłusznych oskarżeń wobec króla polskiego o uprowadzenie metropolity. Był to zupełny absurd, zwłaszcza że konflikt między Dosofteiem a Cantemirem istniał już wcześniej i był sprawą doskonale znaną. Błędem było jednak potraktowanie przedmiotów wywiezionych przez Dosofteia jako zdobyczy wojennej i niezwrócenie ich Mołdawii, lecz przekazanie cerkwiom na terenie Rzeczypospolitej. Ich poszukiwanie i odzyskiwanie po zawarciu układu pokojowego trwało kilkadziesiąt lat ${ }^{30}$.

Mimo wycofania się wojsk polskich z większości okupowanych terytoriów w Mołdawii Sobieski nie rezygnował i w 1687 roku przygotował następną wyprawę. Tym razem miał ją poprowadzić hetman wielki koronny Stanisław Jabłonowski wraz z synem królewskim Jakubem. Wyprawa utknęła jednak pod Kamieńcem i w ogóle nie dotarła do Mołdawii. Tymczasem mimo złych doświadczeń nie rezygnowano z prób porozumienia się z panującym w Mołdawii hospodarem. Ten ostatni zresztą robił wrażenie osoby, z którą można się porozumieć. W połowie marca 1687 roku wysłany został do króla polskiego kluczar Diamant w celu zawarcia układu ${ }^{31}$. $\mathrm{Z}$ królem spotkał się najprawdopodobniej $\mathrm{w}$ kwietniu. $\mathrm{Z}$ niewiadomych przyczyn

28 C. Chowaniec, Wyprawa Sobieskiego..., s. 75.

29 Diariusz kampanii w wołoskiej ziemi 1686 r. królewicza Jakuba Sobieskiego [w:] C. Chowaniec, Wyprawa Sobieskiego..., s. 104.

30 M. Sokołowski, Spadek po metropolicie suczawskim Dositeuszu i jego losy, Sprawozdania Komisji AU do badania Historii Sztuki w Polsce, t. IV, Kraków 1891, s. 87-105; T. Cojocaru, Metropolita suczawski Dosoftei (1624-1693) a Rzeczpospolita, „Balcanica Posnaniensia. Acta et Studia” 2003, t. XIII, s. 235-251. Ciekawy, nieznany dotychczas materiał na temat zwrotu wywiezionych przez Dosofteia przedmiotów zob.: Archiwum Historyczne w Wilnie, F. 1280, op. 1, 700/660.

31 Diamant do Marcina Zamoyskiego, 3 V 1687, AGAD, AZ, 466, nr 1. 
do porozumienia jednak ostatecznie nie doszło. Później nie sprzyjały temu działania wojenne prowadzone na pograniczu mołdawskim i częste podjazdy wysyłane na terytorium Mołdawii ${ }^{32}$. Do rozmów powrócono z początkiem roku 1688. Cantemir wysłał wówczas do króla pârcalaba orcheiowskiego Sawę. Tym razem przebieg negocjacji był bardziej owocny. Dnia 26 maja 1688 roku Jan III Sobieski wydał dla Mołdawii przywilej protekcyjny. Zgodnie z dokumentem brał państwo mołdawskie oraz panującego w nim hospodara pod swoją opiekę, zapewniał Constantinowi Cantemirowi dożywotnio tron, utrzymanie wszystkich praw dla bojarów i duchowieństwa. Tym ostatnim król polski wydał też odrębny przywilej ${ }^{33}$. Wszystko wskazuje jednak na to, że dokumenty te pozostały aktami jednostronnymi.

W tym samym czasie hospodar wołoski Şerban Cantacuzino finalizował podobny układ z cesarzem Leopoldem, i trudno się temu dziwić. Wpływy polityczne cesarstwa były tam silniejsze niż wpływy polskie, dyplomacja cesarska sprawniejsza, a i sukcesy militarne mogły stwarzać wrażenie większego bezpieczeństwa dla słabszych sojuszników. Nagła śmierć Şerbana Cantacuzino w październiku 1689 roku nie zmieniła polityki wołoskiej w sposób zasadniczy, choć nowy hospodar, notabene siostrzeniec poprzedniego, Constantin Brâncoveanu początkowo musiał zaangażować się militarnie po stronie osmańskiej. W 1690 roku otwarty został kolejny front zmagań wojennych - Siedmiogród. Zwycięstwo nad wojskami cesarskimi pod Zernest (Zărneşti - 21 sierpnia 1690), odniesione wspólnie z Imrém Thökölyem ${ }^{34}$, umożliwiło temu ostatniemu opanowanie części Siedmiogrodu i koronację na jego księcia. Wódz powstańców węgierskich musiał być w stałym kontakcie z królem polskim, ponieważ Jan III natychmiast po zwycięstwie przekazał mu gratulacje. Niewątpliwie w stałym kontakcie z nim pozostawali Stanisław Jabłonowski i François de Bethune ${ }^{35}$.

Imré Thököly zresztą natychmiast dołączył do starań ambasadora francuskiego u Porty Otomańskiej o doprowadzenie do separatystycznego pokoju polsko-tureckie$\mathrm{go}^{36}$. W świetle źródeł węgierskich do zawarcia pokoju nie doszło wówczas z powodu zbyt wygórowanych żądań Polaków, którym nie wystarczał zwrot utraconych ziem

32 Constantin Cantemir do Marcina Zamoyskiego, 12 VII 1687 i 28 VIII 1687, AGAD, AZ, 466, nr 2 i 3.

33 Constantin Cantemir do Marcina Zamoyskiego, 29 I 1688, AGAD, AZ, 466, nr 4; Jan III, Przywilej protectiej temu jaśnie wielmożnemu wojewodzie $i$ hospodarowi..., B. Czart., rkps 1164, s. 471-473; Gh. Duznichevici, op. cit., s. 298-299.

34 W historiografii rumuńskiej głównym zwycięzcą w tej bitwie był hospodar wołoski Constantin Brâncoveanu (C. Rezachevici, Constantin Brâncoveanu. Zărneşti 1690, Bucureşti 1989; Constantin Brâncoveanu, coord. P. Cernevodeanu, F. Constantiniu, Bucureşti 1989). Według historiografii węgierskiej jedynym zwycięzcą był Imré Thököly (L. Szadeczky, Thököly Erdélyi fejedelemsége, Budapest 1898) i taką wykładnię przyjęła powszechnie literatura europejska. Wszyscy notorycznie pomijają trzeciego koalicjanta - serdara osmańskiego Çerkez Ahmeda, który zginął w tej bitwie.

35 Dziennik Imré Thökölya - Monumenta Hungariae Historica: Scriptores, t. 23, Budapest 1868, s. 44.

36 P.A. Chateneauneuf de Castagnères do F. de Bethune'a, luty 1690 [w:] E. Hurmuzaki, op. cit., supl. 1, vol. 1, s. 282; N [P.A. Chateneauneuf de Castagnères?] do Ludwika XIV, b.d. [koniec 1690] [w:] ibidem, s. 290. 
wraz z Kamieńcem Podolskim, lecz wysuwali dalej idące roszczenia terytorialne. Jak wiadomo, sprawa była o wiele bardziej złożona i ostatecznie ułatwiła stronie polskiej negocjacje z cesarzem odnośnie do kolejnej wyprawy do Mołdawii ${ }^{37}$.

Constantin Cantemir również uznał, że korzystniejsza dla niego będzie współpraca z cesarzem niż z królem polskim. Jeszcze 15 lutego 1690 roku podpisany został traktat, w którym hospodar mołdawski poddawał się pod protekcję cesarza Leopol$\mathrm{da}^{38}$. Jednak w Mołdawii silne było stronnictwo propolskie, które było jednocześnie stronnictwem antycesarskim. Na czele tego stronnictwa stali wówczas bracia Miron i Weliczko Costin. Weliczko piastował wówczas stanowisko hetmana, natomiast Miron był już tylko wówczas starostą (pârcalabem) na Putnie, nadal zachował jednak ogromne wpływy polityczne. Świadczy o tym fakt, że na dwa miesiące całkowicie zablokował działalność polityczną państwa, starając się nie dopuścić do ratyfikacji układu z cesarzem. Dopiero gdy hospodar zagroził mu śmiercią i wygubieniem całej rodziny, ugiął się i zgodził na ratyfikację. Nie miało to już wprawdzie większego znaczenia, gdyż wkrótce Habsburgowie utracili władzę w Siedmiogrodzie na rzecz Imrégo Thökölya, co musiało przekonać Cantemira o niepewności także i tego sojuszu.

Zanim jednak jesienią 1691 roku kolejna wyprawa polska wyruszyła do Mołdawii, nastąpił zwrot sytuacji polityczno-militarnej. Thököly został wyparty z Siedmiogrodu, a Ludwik Badeński odniósł zwycięstwo nad Turkami pod Zalankamény (Slankamen - 19 sierpnia 1691), gdzie na polu walki zginął wielki wezyr Mustafa Köprülüzade pasza. Cesarz Leopold stracił motyw do współdziałania z Sobieskim. Nie udało się również królowi polskiemu skłonić Rosji do podjęcia równoczesnej wyprawy na Krym. Przekonanie hospodara do współpracy okazało się jeszcze trudniejsze. Cantemir wyraźnie i jednoznacznie sprzeciwił się wkroczeniu wojsk polskich do Mołdawii, zwłaszcza że w kraju grasowały oddziały tatarskie. Jan III Sobieski, mimo wszystko, ciągle liczył na współpracę hospodara mołdawskiego, a przynajmniej licznych bojarów i ludności. Wkraczając do Mołdawii w sierpniu $1691 \mathrm{roku}$, wydał uniwersał zachęcający wszystkich do współpracy i pomocy ${ }^{39}$. Tym razem nie wywołał on takiego oddźwięku jak pięć lat wcześniej, poparcia udzielili królowi jedynie Mołdawianie znajdujący się w służbie polskiej. Hospodar w listach z 2 października, oficjalnym i prywatnym, ostrzegał króla przed kontynuowaniem wyprawy, przekonując, że grozi to zniszczeniem kraju przez Turków i Tatarów, a także naraża na niebezpieczeństwo jego dwóch synów przebywających w charakterze zakładników w Stambule ${ }^{40}$.

Mimo wszystko pod względem wojskowym wyprawa przebiegała pomyślnie. W rękach polskich znalazły się niemal wszystkie ważniejsze twierdze w północnej

37 P. Smolarek, Kampania mołdawska Jana III roku 1691, Oświęcim 2015, s. 24-29.

38 G. Giurescu, Tractatul lui Cantemir cu Austrieci, „Convorbiri Literare” 1910, s. 277-280.

39 Kopia uniwersału j.k.m. do hospodara i obywatelów ziemi mołdawskiej z obozu spod Krasnego Targu [w:] K. Sarnecki, Pamiętniki z czasów Jana III Sobieskiego. Diariusz i relacje z lat 1691-1696, oprac. J. Woliński, Wrocław 1958, s. 14-16.

40 Biblioteka ZN im. Ossolińskich we Wrocławiu, rkps 404, s. 375-378; druk: I. Corfus, Documente privitoare ka istoria românilor culese din arhivele polone. Secolul al XVII-lea, Bucureşti 1983, s. 329-330. 
Mołdawii: Soroka, Suczawa, Neamţ, Cîmpulung oraz obwarowane monastery Hîngul, Săcul i Agapia. Biorąc pod uwagę fakt, że już od poprzedniej wyprawy polskie wojsko przejęło Chocim i okręg czerniowiecki, bilans zdobyczy obiektów wojskowych na terenie prowadzonych działań wojennych był niemal stuprocentowy. Dalszy marsz wstrzymał jednak śnieg, który pojawił się wyjątkowo wcześnie - już w połowie października - uniemożliwiając wyżywienie koni ${ }^{41}$. Mimo konieczności ewakuacji armii i ogromnych strat, przede wszystkim w koniach i sprzęcie, ale także w ludziach z powodu epidemii, wyciągnięto wnioski z poprzednich kampanii i zawczasu należycie zaopatrzono zdobyte twierdze. Pozwoliło to na utrzymanie części z nich przez kilka następnych lat. Specyfika krajów rumuńskich polegała na tym, że opanowanie twierdz nie musiało być równoznaczne z opanowaniem kraju, jednak właśnie ich posiadanie stało się najważniejszym elementem przetargowym w późniejszych negocjacjach pokojowych w Karłowicach. Już zresztą w roku następnym chan tatarski proponował królowi polskiemu mediację i zawarcie separatystycznego pokoju z Turcją na zasadzie wymiany zajętych terytoriów. Strona polska uporczywie domagała się Mołdawii lub przynajmniej północnej jej części, na co Turcy nie mogli się zgodzić ze względu na posiadanie przez nich Kamieńca Podolskiego ${ }^{42}$.

Mimo że król Jan III traktował tę wyprawę jako wstęp do kolejnej kampanii, którą zamierzał podjąć w roku następnym, rok 1691 okazał się przełomowy w relacjach polsko-mołdawskich.

Czynników, które zmusiły króla do wycofania się z aktywnych działań na terenie Mołdawii, było kilka. Najpoważniejsze stanowiły oczywiście trudności w szybkiej odbudowie armii i sprzętu wojennego oraz pogarszający się stan zdrowia władcy. Niemniej istotna była jednak likwidacja propolskiego stronnictwa politycznego w Mołdawii, kierowanego przez braci Costinów, która nastąpiła w grudniu 1691 roku. Nie miała ona wprawdzie bezpośredniego związku z kampanią wojenną króla polskiego, jednak pozbawiła go niezbędnego wsparcia w Mołdawii na przyszłość. Nawiasem mówiąc, stacjonowanie króla $\mathrm{w}$ majątkach przychylnych mu bojarów spowodowało ich zniszczenie, w dalszej kolejności trudności z opłaceniem podatków i niejednokrotnie utratę posiadłości. Po śmierci Petryczejki w 1690 roku zmniejszyło się też znaczenie emigracji mołdawskiej. Wprawdzie po 1685 roku król polski postawił ją na dalszym planie, ale zawsze można było wrócić do koncepcji osadzenia na tronie któregoś z przywódców emigracyjnych. Zabrakło jednak kogokolwiek na tyle znaczącego, by mógł odegrać rolę lidera.

Thököly natomiast niezmiennie uważał króla polskiego i Polaków za swoich przyjaciół. Gdy przepadła wszelka nadzieja na wskóranie czegokolwiek na Węgrzech,

${ }_{41}$ Przebieg kampanii zob.: P. Smolarek, op. cit., s. 43-65. Autor bardzo krytycznie oceniał całą kampanię, deprecjonując wszelkie jej sukcesy. Niewątpliwie jednak nie był w Mołdawii, przynajmniej przed napisaniem tej pracy, nie znał panujących tam warunków. Świadczy o tym fakt, że jedną z najtrudniejszych do zdobycia twierdz, Neamţ, nazywał ,małą forteczką”, nie doceniał też opanowania Suczawy.

42 Zob. np. P.A. Chateneauneuf de Castagnères do Polignaca, 31 X 1690 [w:] E. Hurmuzaki, op. cit., supl. 1, vol. 1, s. 314. 
począł on szukać możliwości uzyskania polskiego indygenatu ${ }^{43}$. W tym czasie już jednak król polski był bardzo chory i negocjacje prowadzono ze Stanisławem Jabłonowskim, zarówno bezpośrednio, jak i korzystając z pośrednictwa francuskiego. Nie udało się jednak doprowadzić tej sprawy do szczęśliwego finału.

W podsumowaniu nasuwają się następujące wnioski:

1. W polityce Jana III Sobieskiego zarówno wobec księstw rumuńskich, jak i wobec powstania węgierskiego zabrakło jednolitego i konsekwentnie realizowanego planu.

2. Za krótkowzroczne uznać należy rozdmuchanie pożaru rewolucji węgierskiej, który wobec włączenia się Turcji Osmańskiej stał się groźny także dla Rzeczypospolitej.

3. W odniesieniu do księstw rumuńskich Sobieski znajdował się w sytuacji błędnego koła. Mógł walczyć z Turkami jedynie na odcinku mołdawskim, jednak nie zdołał pozyskać pełnej zgody na działania ani ze strony cesarza, ani hospodara, nie mówiąc już o współpracy.

4. Ocena rezultatów wypraw Jana III do Mołdawii nie powinna być tak negatywna, jak się powszechnie przyjmuje. Obydwie kampanie mołdawskie przyniosły sukcesy i trwałe zdobycze, straty nastąpiły w wyniku działań czynników obiektywnych. Faktem jest jednak, że kampanie wojenne podejmowano zbyt późno (zwłaszcza w 1691 roku) i pokładano zbyt duże nadzieje w pomocy hospodara oraz mieszkańców Mołdawii. Sobieski fałszywie oceniał nastroje panujące w społeczeństwie mołdawskim, spodziewając się powszechnego entuzjazmu i poparcia. Tymczasem, mimo starań króla, przebieg obydwu kampanii nie przysporzył mu popularności, jego działania odbierano bardzo źle i do dziś jest on postacią postrzeganą w Mołdawii i Rumunii negatywnie.

\section{BIBLIOGRAFIA}

\section{Źródła rękopiśmienne}

AGAD, Archiwum Publiczne Potockich 47, t. 1-2.

AGAD, Archiwum Zamoyskich 466, 2872.

Archiwum Historyczne w Wilnie, F. 1280, op. 1, 700/660.

Archiwum PAN Warszawa, sygn. III-198, nr 91, k. 95.

Biblioteka Kórnicka PAN, rkps 387.

Biblioteka Narodowa w Warszawie, Biblioteka Ordynacji Zamoyskich, rkps 1188.

Biblioteka XX. Czartoryskich w Krakowie, rkps 412, 1164.

Biblioteka ZN im. Ossolińskich we Wrocławiu, rkps 404.

43 „Sunt obligatus Vestrae Excellentiae, quod Excellentissimo Domino legato Polonico indigenatus mei Polonici mentionem fecerit; juxta intimationem Vestrae Excellentiae pro eo indigenatu assequendo ... humillime scripsi in aulam Gallicam" - pisał do posła francuskiego 20 III 1694, Monumenta Hungariae Historica: Scriptores, op. cit., s. 168. 


\section{Źródła drukowane}

Archiwum Spraw Zagranicznych Francuskie do dziejów Jana Trzeciego, wyd. K. Waliszewski, t. 1, Kraków 1879, t. 2, Kraków 1881.

Cantemir D., Viaţa lui Constantin Cantemir, Bucureşti 1973.

Corfus I., Documente privitoare ka istoria românilor culese din arhivele polone. Secolul al XVII-lea, Bucureşti 1983.

Costin M., Latopis Ziemi Mołdawskiej i inne utwory historyczne, tłum. I. Czamańska, Poznań 1998.

Gróf Thököly Imré levelei, Budapest 1882.

Hurmuzaki E., Documente privitoare la istoria românilor, supl. 1, vol. 1, Bucuresci, supl. 2, vol. 3, Bucuresci 1900.

Monumenta Hungariae Historica, Erdélyi Országgyülési Emlékek, t. XVIII (og. zb. XXX), ed. S. Szilágyi, Budapest 1895.

Monumenta Hungariae Historica: Scriptores, t. 23, Budapest 1868.

Pisma do wieku i spraw Jana Sobieskiego, t. 1-2, wyd. F. Kluczycki, Kraków 1881.

Sarnecki K., Pamiętniki z czasów Jana III Sobieskiego. Diariusz i relacje z lat 1691-1696, oprac. J. Woliński, Wrocław 1958.

Szadeczky L., Thököly Erdélyi fejedelemsége, Budapest 1898.

Volumina legum, t. V, Petersburg 1860.

Załuski A., Epistolarium historico-familiarium, t. 1, p. 2, Brunsbergae 1709.

Źródła do poselstwa Jana Gnińskiego wojewody chełmińskiego do Turcji w latach 16771678, wyd. F. Pułaski, Warszawa 1907.

\section{Literatura}

Ágoston G., Óborni T., A tizenhetedik század története, Pannonica Kiadó 2000.

Chowaniec C., Miron Costin en Pologne, Contributions a l'année 1684-1685, nadb. z Închinare lui Nicolae Iorga, Cluj 1931.

Chowaniec C., Wyprawa Sobieskiego do Mołdawii w 1686 r., Oświęcim 2015.

Chowaniec C., Z dziejów powiedeńskiej polityki Jana III. Do genezy sprawy wschodniej, „Przegląd Współczesny” 1929, R. 8, t. XXX, s. 321-341.

Cojocaru T., Metropolita suczawski Dosoftei (1624-1693) a Rzeczpospolita, „Balcanica Posnaniensia. Acta et Studia” 2003, t. XIII, s. 235-251.

Constantin Brâncoveanu, coord. P. Cernevodeanu, F. Constantiniu, Bucureşti 1989.

Czamańska I., Oswobodziciel czy najeźdźca? Polityka Jana III Sobieskiego wobec hospodarstw Mołdawii i Wołoszczyzny, „Roczniki Historyczne” 1989-1990, t. XV-XVI, s. $151-177$.

Czamańska I., Rumuńska imigracja polityczna w Polsce XVII wieku, „Balcanica Posnaniensia. Acta et Studia" 1993, t. VI, s. 5-22.

Duznichevici Gh., Ceva nou asupra legăturilor lui Sobieski cu Moldova, AR MSI, ser. III, t. 19, mem. 21, Bucureşti 1937.

Giurescu G., Tractatul lui Cantemir cu Austrieci, „Convorbiri Literare” 1910, s. 277-280. 
Michaud C., Le soleil, l'aigle et le croissant. L'ambassade de Guilleragues à la Porte Ottomane et le siège de Vienne de 1683, „Revue des Études Sud-Est Européennes” 1984, t. XXII, p. 2, s. 145-158.

Michaud C., Raison d'état et conscience chrétienne. L'ambassade du marqis de Nointel auprès de la Porte Ottomane, „Revue des Études Sud-Est Européennes” 1979, t. XVII, p. 2, s. 257-267.

Moga I., Rivalitatea polono-austriacă şi orientarea politică ţărilor române la sfârşitul secolului XVII, Cluj 1933.

Rezachevici C., Constantin Brâncoveanu. Zărneşti 1690, Bucureşti 1989.

Smolarek P., Kampania mołdawska Jana III roku 1691, Oświęcim 2015.

Sokołowski M., Spadek po metropolicie suczawskim Dositeuszu i jego losy, Sprawozdania Komisji AU do badania Historii Sztuki w Polsce, t. IV, Kraków 1891, s. 87-105.

Spieralski Z., Awantury mołdawskie, Warszawa 1967.

Vandal A., L'odyssée d'un ambassadeur. Les voyages du marqis de Nointel (1670-1680), Paris 1900.

Wasilewski W., Wyprawa bukowińska Stanisława Jabłonowskiego w 1685 roku, Warszawa 2002.

Wdowiszewski Z., Regesty przywilejów indygenatu w Polsce (1519-1793), Materiały do biografii, genealogii i heraldyki polskiej, t. 5, Buenos Aires-Paryż 1971.

Woliński J., Z dziejów wojen polsko-tureckich, Warszawa 1983.

Wójcik Z., Jan Sobieski 1629-1696, Warszawa 1983.

Власова Л.В., Молдавско-польские политические связи в последней четверти XVIIXVIII вв., Кишинев 1980. 